\title{
Evaluation of Hepatitis B Surface Antigen Rapid Test in Detection of Hepatitis B Virus Infection in Salahaldin Governorate, Iraq, 2012
}

Abbas Abbas; A Sameer

\section{Corresponding Author:}

Abbas Abbas

\section{Abstract}

Background: Hepatitis B virus (HBV) can be detected by different serological and molecular biological methods. Nationally, high laboratory cost and lack of availability of Enzyme linked immunosorbent assay (ELISA) technique in peripheral health facilities raise the need for evidence-based decision on the use of HBs Ag rapid test in detection of HBV infection.

Objective: to evaluate the validity of ACON- HBs Ag rapid diagnostic tests in detection of hepatitis B virus infection in sentinel sites at Salahaldin Province.

Methods: Cross sectional study conducted from 1st March to 1st September 2012 in three sentinel sites at Salahaldin governorate. Depending on Hepatitis B median endemic index of 10\%, a total of 900 subjects of both genders attending these sentinel sites and screened by ELISA technique for HBs Ag presence, were re-screened by the ACON HBs Ag rapid test device. The ACON HBsAg One Step Test is a qualitative, solid phase, two-site sandwich immunoassay for the detection of Hepatitis B surface Antigen (HBsAg) in serum or plasma. Results of both techniques were compared and validity of HBs Ag rapid test was calculated statistically by SPSS version 17.

Results: ACON HBs Ag rapid test showed an overall sensitivity, specificity, positive predictive value, and negative predictive value of $92.8 \%, 99.6 \%, 97.9 \%$, and $99.2 \%$ respectively. But nothing is perfect. These rapid tests fail to detect HBs Ag concentrations between the cutoff value to $<1 \mathrm{OD}$ value.

Conclusions: ACON HBs Ag rapid tests proved to be valid in detection of HBV infection in peripheral health care facilities lacking ELISA machine. However, at these facilities we should depend on ELISA technique in detection of HBV infection in those subjects requiring invasive procedures.

(iproc 2018;4(1):e10620) doi: $10.2196 / 10620$

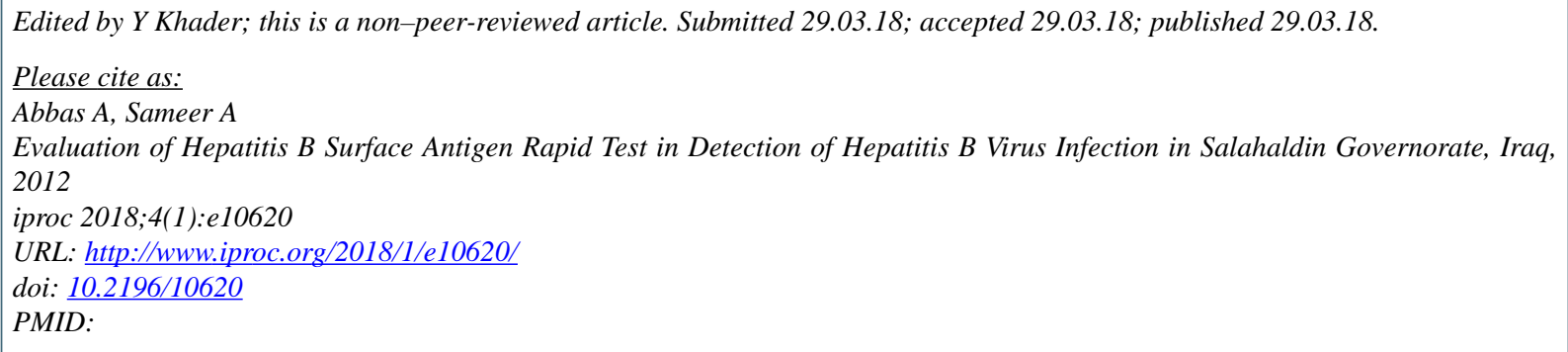

(C)Abbas Abbas, A Sameer. Originally published in Iproceedings (http://www.iproc.org), 29.03.2018. This is an open-access article distributed under the terms of the Creative Commons Attribution License (https://creativecommons.org/licenses/by/4.0/), which permits unrestricted use, distribution, and reproduction in any medium, provided the original work, first published in Iproceedings, is properly cited. The complete bibliographic information, a link to the original publication on http://www.iproc.org/, as well as this copyright and license information must be included. 